\title{
Parents, Teachers and Community Relations in Promoting Learning in the Secondary School System in Nigeria
}

\author{
Jessica Ezekiel-Hart ${ }^{1, *}$ \\ ${ }^{1}$ Department of Educational Foundations and Management, Ignatius Ajuru University of \\ Education, Port Harcourt, Nigeria \\ *Correspondence: Tel: 234-803-707-2197Ｅ-mail: jessvalhart@yahoo.com
}

Received: June 2, 2013 Accepted: August 15, $2013 \quad$ Published: September 11, 2013

doi:10.5296/ije.v5i3.4262 URL: http://dx.doi.org/10.5296/ije.v5i3.4262

\begin{abstract}
Schooling, a relatively recent invention which emerged as society became more complex, has become the major agent of education worldwide. Being that schools do not exist in a vacuum, they alone cannot successfully perform this function. Because schools emanate from communities, the latter must exercise ownership by being both the determiners and determinants of education. This paper therefore presents how a relationship can be formed among the principal stakeholders - parents, teachers and community to foster quality in education, a situation in which the student is the immediate beneficiary and the society the ultimate beneficiary. If teacher/school treats parent/community as powerless or unimportant, the latter will be discouraged from taking interest in school thus promoting the development of attitudes which inhibit achievement among students. Conversely schools that synergistically work with these stakeholders do better in all areas.
\end{abstract}

Keywords: parents; teachers; community; secondary school; learning 


\section{Introduction}

Education has always existed in human societies regardless of the stage of evolution of a society but schooling is a relatively recent invention which emerged as society became more complex and division of labour set in (Ezekiel-Hart 2011). In most modern societies the school has become the major agent of education. Ideally, since schools emanate from society the ownership resides in the community. Whenever this ownership is absent schools and the education they deliver become dysfunctional.

In reviewing several research studies which examined evidences regarding the effect of parent/community involvement on student academic achievement and performance in schools, Henderson (2002) and Epstein(2001) concluded that schools that work well with families show improved morale, produce higher ratings of teachers by parents and have better reputation in the community. Yet in Nigeria, participation is very minimal, particularly at the secondary school level. Therefore, the focus of this paper will be on how to achieve this quadruple relationship which promotes quality learning in schools.

\subsection{Elucidating Key Concepts}

The key concepts here are teachers, parents, community, secondary school.

\subsubsection{Teacher}

Who is a teacher?

A teacher is not just a person who stands in front of learners in a class, neither is he the one who merely instructs, nor one who is knowledgeable in certain areas. Rather, he is one who has the ability to command societal respect as a role model to all. He is key in bringing about desirable learning outcomes. The Federal Government of Nigeria (2004) in her national policy on education emphases this truism that teachers' quality and quantity are critical to meaningful attainment of goals and objectives But it is often erroneously assumed that anyone with a university qualification from a Faculty of Education or a qualification from a College of Education is a teacher. But a qualified teacher is not necessarily a competent teacher and the latter may not necessarily be an efficient teacher; just as the efficient one may not be an effective teacher. To be more specific;

A qualified teacher has the minimum acceptable qualification for teaching. A competent teacher has mastered all the principles of teaching as taught. An efficient teacher can apply the principles as learnt. An effective teacher applies the principles so creatively that students' learning is maximized. Quality teachers therefore are qualified, competent, efficient and above all effective.

These four classes of teachers operate at five corresponding levels of teaching.

- The qualified teacher: Level 1 (Dictatorial) The all knowing teacher who "stuffs the empty heads" of students with knowledge.

- The competent teacher: Level 2 (Didactic) He has learnt the formal pedagogical rules and follows them keenly. 
- The efficient teacher: Levels 3 and 4- (Demonstrative, interactive) this teacher allows limited student input, can also encourage student participation, but still thinks within the box.

- The effective teacher: Level 5 (Creative) He creates responsiveness to specific teaching learning challenges.

Today schools seem to be teaching without teachers (Obanya, 2006). This absence can be measured in numerical strength and in qualitative terms. There is an abysmal dearth of teachers in the rural areas and qualitatively there are defects in teacher preparation, the way teachers go about their jobs, societal disrespect for teachers, non-involvement of teachers in matters concerning education to mention just a few. The way teaching is done without interactivity does not lead to any transformation in the learner. Without creativity there can be no creative people who can transform society. A good understanding of teachers' handicap calls for teacher professional support - a systematic process of ensuring teacher continuous professional development with constant needs assessment of the teacher and adequate opportunity for relearning, re-skilling and re-tooling.

\subsubsection{Parents}

The Webster dictionary defines parents as someone who begets or gives birth to offspring. But the word has a wider meaning, particularly in Africa, as it includes significant others in the life of a child. For this reason this paper will, where necessary, substitute home for parents.

In assessing the contribution of the home in educational success, distinction must be made between status and process variables. The former deals with materials endowment while the latter deals more with "how the family views and leads life". Examples of each of these variables is presented in table one below.

Table 1: Status and process variables in a child's home environment

\begin{tabular}{ccc}
\hline STATUS VARIABLES & PROCESS VARIABLES \\
\hline - Level of education of father & - & Values upheld by the family \\
- Level of Education of mother & - & Prevailing parenting practices \\
- Occupational status of father & - & Quality time spent with children by father \\
- Occupational status of mother & - & Stable home environment \\
- Family income & - & Parental aspirations \\
- Family size & - Level of parental support to the school \\
- Level of material comfort & - Ethnical climate of the home \\
& - Tone of discipline in the home \\
\hline
\end{tabular}

Numerous studies by international Association for the evaluation of educational Achievement (IEA) show a correlation between home background variables and academic achievement (www.unesco.org). In all, process variables account more for the variance in scores. Blooms (1980) collaborates these findings.

The process variables do contribute more to educational success (adjustment to school, achievement motivation, good study habits, positive self-concept, successful learning, etc.). Of 
the status variables, mother's level of education plays a greater part in promoting educational success than any of the other factors. It must however be admitted that the status has to be there for the processes to be in place. But this is not true in every family situation, as there can be high status families with low process conditions, while some relatively low status families could be high on some process variable, especially on parental aspirations. This in turn does fire achievement motivation in children, in addition to activating the development of other process conditions in families that are materially not quite well off.

The implication of this therefore is that one must look beyond what the home is (in terms of status) to the genuine supportive actions of the home. In order words, the process variables should be a more important focus area in creating supportive homes that can synergize with the school to deliver quality education.

\subsubsection{Community}

The most common definition of community is taken to mean a group of people living in the same locality and under the same government (American Heritage Dictionary). Communities are made up of households who in most cases share all forms of contiguities - geographical, historical, sociological, political characteristics. The adage that it takes a village to raise a child (ji4d.org) summarizes community involvement in the education of a child and this is the norm in traditional African society. But with the advent of Western Education Community involvement waned leaving only family members, particularly mothers, to assist in their children education. Even this assistance is grossly limited to helping the child with his/her home work, doing school runs and in very rare cases being physically present in class to assist teachers. Today advocates of community participation call for more inclusiveness, involving mother, father, step parent, grandparents, foster parents, other relatives and care givers, business leaders and community groups, all participating in goal oriented activities. Home based activities such as helping children read and write and promoting school attendance can best be handled by the parents but school based activities such as attending P.T.A (Parent Teacher Association) meetings, parent teacher conferences, helping to raise money etc will best be handled by the community. The importance of community involvement in school cannot be over emphasised because what happens outside in school is as important as what happens within the school. Learning does not begin and stop in the classroom. How to make community get involved will be discussed later.

Today, Nigeria and a good number of African Countries have built- in School Management Committees (SMC) into their educational management at the institutional level. Much as that is a welcomed development, the real issue is not their existence but the extent to which they are functional. Certainly SMC can be a veritable instrument in bringing about a sound and beneficial relationship between community and school.

\section{Secondary School}

This is the post primary subsector of education. Nationally and internationally secondary education appears not to have been given its fair share of attention. Judging from the 1990 decade which was characterized by the holding of grand world conference on education and 
human development, secondary education, as important as it is, was never considered. Table 2 shows a list of eighteen conferences out of which three were in basic education, one in higher education, one in adult education, one in technical education and non in secondary education.

Table 2: Global grand education-related conferences of the 1990 (www.eng.unesco-iicba.org)

- World Conference on Education for All (Jomtien) 1990

- World summit for children (New York) 1990

- United Nations Conference on environment and Development (Rio de Janeiro) 1992

- International Conference on Education for Human Rights and Democracy (Montreal) 1993

- $\quad$ The E-9 Summit (New Delhi) 1993

- World conference on Human Rights (Vienna) 1993

- World Conference on Special Needs Education (Salamanca) 1994

- International Conference on Population and Development (Cairo) 1994

- World Summit on Social development (Copenhagen) 1995

- Fourth World Conference on Women (Beijing) 1995
- Mid-Decade review meeting of the International Consultative Forum on Education for All (Amman) 1996

- Fifth International Conference on Adult Education (Hamburg) 1997

- First World Conference of Ministers

Responsible for Youth (Lisbon) 1998

- Inter-Governmental Conference on Cultural Policies for Development (Stockholm) 1998

- World Conference on Higher Education (Paris) 1998

- World Conference on Higher Education (Paris) 1998

- Second International Congress on Technical and Vocational Education (Seoul) 1999

- Education for All (EFA) Forum - Dakar 2000

This has led some commentators to observe that secondary education is being treated by global policy influence body as a second child.

When the first child is born, there is joy all over

When the second is born, the reaction is that of déjà vu

With the last baby, parental response is one of eternal pampering (Obanya, 2012).

Global interest in secondary education was kindled during the 2000 decade. A major interest was demonstrated by the World Bank which came up with a draft policy guideline of secondary education that was reviewed by an international advisory group. The product of the review was published as "Expanding Opportunities and Building Competence for the Youth" in 2005. Much as this report was not widely publicized, it has remained the World Bank leading document on secondary education.

The World Bank interest in secondary school again was seen in its involvement with SEIA (Secondary Education in Africa) project that involved studies in a number of African countries and the holding of four regional consultative conferences, Mauritius (2001) Kampala (2003) Dakar (2004) and Accra (2007). The findings and recommendations of these studies and conferences have been incorporated into the SEIA Synthesis Report. This discussion paper is 


\section{Macrothink

meant to promote dialogue within and between African countries and the broader international donor community in the choices available for sustainable expansion of secondary education and training systems (worldbank.org/education/africa).

Arising from SEIA, Nigeria inaugurated SEIN (Secondary Education in Nigeria) project which consisted of an overall national survey, followed by four in depth studies at state levels-Enugu, Kaduna, Lagos and Rivers. Among the result of these studies was the need for greater community involvement in promoting quality, but above all the report emphasized the need for more systematic planning of the development of secondary education. This is a sine qua non seeing that what goes on education, particularly in the secondary school, is impulsive rather than reflective approach.

The effort of parents and community to foster a relationship with teachers, a relationship which will engender quality in education, will be an exercise in futility if schools do not provide an enabling environment, for quality education. To be an instrument for qualify education; school should have a certain number of attributes which combine to create an enabling environment. These attributes are presented in five clusters below.

Table 3: Five Major Features of the School

CLUSTER ONE: Physical /environmental features

- Physical space - attractive and inviting

- Adequate space for in-class and out-of class learning activities

- Classrooms with adequate sitting and move around spaces

- Adequate lighting-ventilation and security of classrooms and other teaching teaching-learning spaces

- Classrooms furniture that do not squeeze students

CLUSTER TWO: Managerial/organizational features

- Participatory decision-making-making

- Healthy school-community relationship

- Free information flow

- Team spirit prevailing

- Encouragement of creativity in teachers

CLUSTER THREE: Teaching-learning facilities

- Quantitatively adequate

- Timely/current/up-to-date

- Closely attention to student learning difficulties

- Special attention to student learning difficulties

- Practice of empathy (towards learners) by all teachers 
CLUSTER FIVE: Pedagogical Features

- General and professional education of teachers

- Level of experience of teachers

- Level of teacher knowledge of curriculum

- Efforts at continuing professional development by teachers

- Level of creativity in teachers

- Teacher classroom interaction practices

- Teachers knowledge and application of assessment procedures

Two major lessons can be derived from this table. The first is that a school is not a mere building. It is a lot more than that. As important as school buildings are, they must meet minimum standards for education. The second is that there is a wide gap between establishing a school and merely citing or locating a school. To establish a school means endowing it with all the features that make the delivery of quality education possible. Sometimes schools are cited in Nigeria out of personal considerations which override public interest. This results in the littering of many classroom blocks which do not have the necessary attributes which combine to create an enabling environment. In fact some of these classroom blocks are hardly in use.

\section{How to Effect Relationship}

Let it be emphasized again that this paper is attempting to present how a quadruple relationship (teacher, school, parent and community) can be formed to ensure quality education that will benefit both the individual beneficiary and society at large. The elucidation of the key concepts above is intended to lead to the identification of key areas of intervention that would empower these different stakeholders to ensure effective synergy. The literature on how children learn is replete with the contribution of these stakeholders therefore how can parents and communities be made to be involved in the life of the school and how can teachers and school authorities be made to be involved in the families of their pupils and in the corporate existence of their communities.

For genuine relationship to exist, the stakeholders must have a good knowledge of one another. In this regard the school should know the following basic facts about the community.

a. The composition of the community, for example, the income level of the people in the community, their educational attainment, and occupation of the majority of residents. This is useful in formulating new programmes or adapting existing ones to meet students' particular needs. What language do they speak at home what ethnic traditions do they have.

b. Community opinion regarding both broad and specific educational issues. Specifically the school should know what the community thinks about the teaching staff with regard to its instructional ability fairness to students, discipline etc. Do they participate in the life of the community etc? They may also want to know what the community thinks about the administration, for instance, in terms of its administrative ability. How fair 


\section{Macrothink}

International Journal of Education

ISSN 1948-5476

2013, Vol. 5, No. 3

are they to employees, do they have and operate a local content policy with regards to employment etc.

c. What are the available educational resources in the community?

For example resources for field trips which permit students to see manufacturing processes, industrial development, governmental processes and similar activities. What opportunities are available for cooperation with community organization institutions?

\section{How does School get this Information?}

Information about community is gathered in a number of formal and $\backslash$ or informal ways. The informal include exchanging comments in an informal setting like hair salon, market place, church etc. while the formal is a more scientific way.

Community survey is a formal means of gathering information about a community and here are some tips on the use of survey. Community survey may be conducted by the school board which investigates impact of major policy issues while individual schools can also use survey but on a small scale. Whether at a macro or micro level a survey should never be conducted simply for the sake of conducting a survey. Rather it should be done in response to a problem or a need for getting information e.g. about the educational resources available in the community. The problem/need must be well defined.

The most common type of survey used by schools is the questionnaire and the type of information required determines who it is administered on. A questionnaire relating to general educational issues may have a wide range of respondents than one which seeks information on a narrow topic. In developing the questionnaire, Lucas and Thompson (saskschoolboards.ca) suggest that the following points be considered:

a. The questionnaire should not be so complex and long that it places a burden on the respondents.

b. The questions themselves should not be too long. Lengthy questions can be confusing for respondents.

c. Questions should be clearly stated and direct. Do not ask vague questions such as "what do you think of secondary schools?" A better question is "Do you favour grouping children in grades 7 to 12 in one school”.

d. Do not use overly complex language. The language used should be such that the least educated respondent will be able to understand the questions.

e. Questions should not require written responses. Written responses are difficult to tabulate and time consuming for the respondent. Answers should be either the 'yes, no, no opinion type" or should offer a range of responses such as "excellent, good, fair, poor”

f. Questions should not be stated in a way that favours a particular response over other responses. 
All other procedures of conducting scientific research must be followed.

Having stated earlier that functional SMC is a veritable vehicle for breeding relationship between school and community here is a set of criteria that must be met for SMC to be functional.

\section{A. Membership}

i. Representativeness in terms of gender, religious/social/ethnic, occupational groups in the community, generational mix is required.

ii. Knowledge of the local environment, ability to articulate the needs of the people, a clear perception of the role of members of SMC in driving educational progress in the locality.

iii. Team spirit, there must be synergy of purpose and action

iv. Willingness by members to serve and to take on responsibilities.

\section{B. Operations}
i. Goal-oriented programmes of activity
ii. Respect for democratic principles
iii. Transparency
iv. Regular, statutory, well-attended meetings

v. Systemic record of meetings and reporting of activities

vi. Prompt responses to the needs of the school, teachers, parents and students

vii. Regular communications with government and local community

viii. Mechanisms for mobilizing community involvement

\section{Impact}

i. Cementing school-community relations

ii. Mobilization of resources to supplement government allocations

iii. Conducive working environments for teachers and students

iv. Entrenchment of community involvement

v. Continuous improvement in the quality of education service delivery to the community.

In short, SMCs are functional to the extent to which the membership is representative of the various segments of the community, the extent to which the members are knowledgeable, active and committed. Functionality also has to do with the nature of the programmes undertaken, as well as the entrenchment of democratic practices with its distinguishing characteristics of openness and transparency. These conditions would determine the level of 
the impact that the SMC makes on the system. Ultimate their success will impact positively on the quality of education service delivery in the community. Therefore, the way to go is to move beyond merely establishing SMCs to a concerted move to enhance their functionality. This would be another sure way of promoting synergy between home and school.

\section{Other Ways of Involving Community in School}

\subsection{The Parent-teacher Conference}

This is a very effective means of forging a relationship between teachers and parents and by extension the community. As well as providing information to parents about their child's progress, the conferences allow parents to ask questions about general school policies, programmes and events. Lucas and Thompson(n.d.) (saskschoolboards.ca) developed the following guidelines for a successful parent teacher conference.

- Let the parent know what you would like to accomplish during the conference.

- Establish a friendly atmosphere. Remember you are a host or hostess just as though you were in your own home. The parent may be uneasy and fearful about the conference.

- Have an informal setting. Sit on the same side of a table with the parents, rather than at your desk.

- Remember that you are dealing primarily with one individual child, not comparing him with other members of his or her class.

- Be positive. Begin and end by listing favourable points. Stress the child's strengths.

- Help parents to achieve a better understanding of their child as an individual. Don't attempt to interpret the curriculum in a short conference. This is more appropriate for a group conference.

- Be sure to have at hand samples of the child's work-the whole range, not just those you consider adequate or inadequate.

- Base your judgements on all available facts and on actual situations. Preparation should be made to discuss any standardize group tests that are available.

- Keep vocabulary simple.

- Accept the parent's reason for a child's behaviour without showing signs of disapproval or surprise. If necessary, lead the discussion into additional possible causes of action or attitude.

- Be truthful, yet tactful. The parent should be aware of the child's weaknesses, but nothing is gained by an unkind remark or by putting parents on the defensive. 


\section{Macrothink

- Remember that parents are subjective and emotional about their children. Put yourself in the place of the parent and try to see what effect a given remark would have one you.

- Do not use expressions that imply placing of blame for unacceptable performance.

- Remain poised. Avoid defensive arguments. Talk calmly.

- Select for emphasis from among the child's weaknesses only those the child and parent are ready to deal with constructively.

- Be constructive in suggestions. Don’t “load” parents with suggestions. A few are more effective than many.

- Do not take more notes than are necessary. Take some time at the end of the conference, if necessary, to write notes.

- Help parents to find their own solutions to problems. Agree upon action needed. Go only as far as the parent is ready to accept. We are all afraid of ideas we do not understand.

- Encourage the parent to talk. Be a good listener. You are interested in the information the parent brings to you about this child.

- Do not diagnose health conditions or suggest treatment. Keep discussions to such aspects as fatigue, restlessness, irritability.

- Do not attempt to deal with serious psychological problems of children. Refer such problems to the principal or school guidance counsellor.

- At the close of the conference summarize points covered and suggestions agreed upon.

- Set a time limit. If another parent is waiting, tactfully conclude the conference; suggest further discussions at another time.

- End on a note of continuing cooperation. Cordially invite parents to visit the school again.

\subsection{School Open House}

Many schools hold an open house once or twice a year, usually at the middle and or end of the year. The open house involves parents in the life of the school while offering school the opportunity to display school activities. In promoting open house the following guidelines will be helpful.

- Letters and notes can be sent home with students or mailed to students' homes.

- Have student or employees guide people to the proper parking areas.

- Have the entrance(s) clearly marked and lighted. 


\section{Macrothink}

- Have reading materials or a display of students' work in halls and in the areas where early arrivals will be waiting.

- Place easy-to-read directional signs throughout the building.

- Establish ways for parents to make suggestions for improving the school. Place tape recorders and suggestion boxes in prominent places. Distribute forms that ask parents to evaluate the open house; information gained will enable you to improve it each time.

\subsection{Parent Volunteers}

A volunteer programme brings members of the community to interact with teachers and the school. The volunteers may or may not be parents. In a small community, a principal or teacher may already know those who are willing to volunteer their services and before they are engaged, their job description, as well as who they should report to, must be well spelt out. A volunteer who is doing secretarial work is very likely to work with the school secretary.

\subsection{School Patron}

Prominent persons in the community can be appointed as patrons. While it is a way of honouring such persons they also act as role models to teachers or students. A patron can be invited to address a graduating class, present awards etc.

\subsection{Senior Citizens}

Their wealth of experience can be an asset to the school while helping them ease boredom. The school can invite grandparents or people in a certain age bracket to an open house to share experiences with school or they can be recruited as volunteers.

\subsection{Community Use of School Facilities and School Use of Community Facilities}

A relationship can develop as school and community share facilities school can organized field trips to small business out fits, factories thereby building close ties.

\subsection{Clubs and Associations}

Community resource persons: Community members with special skills can act as resource personnel to students' clubs. For example a local actor can serve as advisor to the school drama club, the editor of a local news paper can relate to members of the school press club.

\subsection{Home Visit}

Home visit by either teachers or principals are a time honoured method of forging a close relationship between teacher, parent and community. A good understanding of the home and community background would give the teacher/school a better understanding of their students. Here are the guidelines to fellow:

- Phone or write before visiting to be sure that you are welcome at a time convenient for the parent. 


\section{Macrothink

- Conversation should be casual and not pointed or embarrassing. If you are to learn anything of value, it will have to come indirectly through observation rather than an inquisition.

- If possible, both parents should be present. Often, the source of difficulty lies in the relation of parents to each other.

- Depending upon the kind of home visited, you should dress appropriately. If a low income family, care should be taken not to overdress, and if a high income family, not to look dowdy.

- Respect the prevailing cultural practices of the family. Don't forget that the teacher is on public display during the visit and can either reinforce or change the parent's image of the school and it staff.

\section{Challenges}

The following can be challenges in the Nigerian context:

- Unwillingness to try something new and the bureaucratic bottle neck of getting approval before certain actions are taken by school.

- Funding - Where school are grossly underfunded, certain actions that need to be financed, for example survey, cannot be undertaken.

- Volunteer work is almost alien. Driven by economic exigencies, Nigerians want to be paid for every conceivable service rendered.

\section{Conclusion}

If properly managed the relationship among teacher, parent, community and school can enhance quality in education. The Centre on Families, Communities, Schools and Children's learning (1994) indicates that parents, who receive frequent and positive message from teachers, tend to become more involved in their children's education than parents who do not. They respond to encouragement from educators and this cascades down to their children. Teachers can promote parent/community relations in various ways which have been stated in this paper. When parents show a strong interest in their children's schooling, they promote the development of attitudes that are key to achievement. Attitude such as motivation is said to be the "heart of learning"," golden road to learning" and "potent factor in learning”. If the teacher/school treats parent/community as powerless or unimportant, if they discourage parents from taking an interest in school, they promote the development of attitudes in parents and consequently their children that inhibit achievement. On their part parents also should be encouraged not to abandon their responsibility as the primary provider of education. Too often, parents erroneously believe that teachers/schools are solely responsible for the education of the young ones; whereas their input in what goes on inside the school and their involvement in the 
lives of their children outside school, add up to quality education delivery.

Parents must also be prepared to bear the opportunity cost of education. This is the sacrifice they will make for education, for example not giving up their daughters early in marriage but allowing them remain in school to graduate. By the same token boys must be encouraged to remain in school and graduate instead of opting out for quick and "easy" money making ventures such as bunkering which rakes in free oil money. Because schools emanate from communities, the latter must exercise ownership by being both the determiners and determinants of education. As determiners they must have a say and as determinants they must have their way. In doing this they should not be unmindful of the complex nature of the classroom in which teachers work.

Allowing all stakeholders to participate in education service delivery will help in building a functional relationship which is capable of revolutionizing the system. A more congenial teaching and learning environment will be established and there will be an increase in the degree of societal respect accorded to teachers and the teaching profession. Finally in a situation like this school cannot be estrange from community. Every suggestion in this paper many not be workable but effective stakeholders would creativity adopt/adapt what works.

\section{References}

Ackers, J. (2006). Concept note, IDP supports to teacher education in Nigeria-A proposal for synergizing our efforts. Abuja: UNICEF.

Bloom, B. (1982). All our children learning. California: UCLA Press.

Bloom, B. S. (1980). The new directions in education and research: Alternable variables in education. In K. D. Sloane \& M. I. Obrien (Ed), The state of research on selected alterable variables in education. Chicago.

Ejieh, M. U. C., \& Kamla-Raj. (2005). Educational quality and community involvement in Nigeria: Some implications for educational planning. Journal of Social Sciences, 10(1), 43-48.

Epstein, J. L. (2001). School, family and community partnerships. Boulder: Westview Press.

Ezekiel-Hart, J. (2011). Reflections on politics and policies of education in the realization of Vision 20:20:20. European Journal of Education Studies, 3(2), 365-374.

Federal Government of Nigeria (2004). National policy on education. Lagos: Author.

Henderson, A. T., \& Mapp, K. L. (2002). A new wave of evidence: The impact of school, family and community connections on students' achievement. Austin, TX: South-West Educational Development Laboratory.

I. E. A. www.encyclopedia.com/do-/1G2-3406900014

Lucas, B., \& Thompson, L. (n. d.) School community relations handbook. Retrieved from 
booksgoogle.co.uk/book/about/school_community

Morris, W. (2000) (Ed.). The American heritage dictionary of the English language.

Nnoli, N., \& Ajayi-Smith, K (n.d). The importance of community involvement in the development of education in Nigeria. Retrieved from ji4d.org

Obanya, P. (2006). Teaching without teachers. $24^{\text {th }}$ Distinguished lecture series, Adeniran Ogunsanya College of Education, Lagos State, Nigeria.

Obanya, P. (2012). Promoting quality education through home school synergy. Faculty of Education, University of Lagos $50^{\text {th }}$ Anniversary Round Table. $9^{\text {th }}$ October.

Obanya, P., Ivowi, U., \& Ezewu, E. E. (2004). Major challenges to the development of secondary education in Nigeria-abridged version of a World Bank study of secondary education in Nigeria.

Ukeje B. O. (1986). Teacher education in Nigeria: Problems and issues. In B.O Ukeje, L.O. Ocho and E.O Fagbamiye (Eds.), Issues and cancerous in educational administration. The Nigerian case in international perspective. Lagos: Macmillan.

Webster dictionary. (1913) www.webster-dictionary.net

World bank.org/education/Africa

\section{Copyright Disclaimer}

Copyright reserved by the author(s).

This article is an open-access article distributed under the terms and conditions of the CreativeCommons Attribution license (http://creativecommons.org/licenses/by/3.0/). 